\title{
AGE OF MARRIAGE OF WOMEN AND LIVE CHILDREN IN FAMILY- ANALYTICAL SURVEY
}

\author{
Rekha Sapkal1, Uttam Onkar Sapkal²
}

1 Professor and HOD, Department of Obstetrics and Gynaecology, PCMS and RC, Bhopal, Madhya Pradesh. 2Associate Professor, Department of Paediatrics, PCMS and RC, Bhopal, Madhya Pradesh.

\section{BACKGROUND}

\section{ABSTRACT}

Women's lives are shaped by the customs of the community. If early marriage is the life event, subsequently available childbearing years increase and grand multiparity is the result. There is proportionate increase in number of children in family. Hence, the study aims to explore the practiced age of marriage with its effect on family size.

Primary objective was to identify the target population to prevent third child birth. Secondary objective was to predict the family size in various past decades according to their past reproductive life.

\section{MATERIALS AND METHODS}

A cross-sectional study was conducted from June 2015 to September 2015. 1667 women in hospital-based population were enrolled and interrogated in local language for their present age, age of marriage and number of child birth they had during their lifespan. Dead issues were excluded from family size. Eligible patients for study included above 15 years, non-pregnant women and who gave consent to be part of the study. Exclusion criteria were pregnant cases and non-willingness to participate. Teenage marriage slab was < 20 yrs., normal age 21 - 30 yrs. and elderly group $>30$ years. The data was analysed statistically to know age of marriage, reproductive lifespan and its relation to family size. According to reproductive period, exposed generation gap was calculated retrospectively. Family size was plotted in the previous years considering the 2015 as a study year, reflecting the changing trends in family size in past decades.

\section{RESULTS}

In the study, current mode of age is 35 years. Average age of cohabitation in the present study is 18 - 28 years. Slab of teenage marriage is $<20$ yrs. Family size of three was observed in 31\%. (Chi-square value $=0.110$, P value $=<0.001 \mathrm{HS}$ ). Next slab of age of marriage is 21 - 25 years, $24 \%$ had only two issues (statistically highly significant). However, with marriage age from > 30 years either no issue or single issue both were observed in $33 \%$ population each.

\section{CONCLUSION}

Average age of cohabitation in the present study is 18 - 28 years. In populations with higher age at marriage, fertility generally observed is low. The earliest current age range to prevent the third child birth is age 26 to 30 years with age of marriage as $18-20$ years. The target population to prevent third child birth is any lady of 31 - 35 years' age group.

\section{KEYWORDS}

Family Size, Age of Marriage, Family Planning, Teenage Marriages, Reproductive Lifespan.

HOW TO CITE THIS ARTICLE: Sapkal R, Sapkal UO. Age of marriage of women and live children in family- analytical survey. J. Evolution Med. Dent. Sci. 2018;7(14):1778-1781, DOI: 10.14260/jemds/2018/401

\section{BACKGROUND}

Women's lives are shaped by the customs of the community. In every society, there is certain norms and customs. India is a country where one sexual partner for lifetime is the practice.

Although, India was the first country to announce an official family planning program in 1952, still till today there is practice of three children in the family. ${ }^{1}$ More number of children in the family, more health related problems to the children. Female education is a stronger determinant of age at marriage and early fertility. ${ }^{2}$ If early marriage is the life event, subsequently available childbearing years increase and grand multiparity is the result.

'Financial or Other Competing Interest': None.

Submission 20-06-2017, Peer Review 14-03-2018,

Acceptance 21-03-2018, Published 02-04-2018.

Corresponding Author:

Dr. Rekha Sapkal,

Professor and HOD,

Department of Obstetrics and Gynaecology,

PCMS and RC, Bhanpur-462023, Bhopal, Madhya Pradesh

E-mail: uttamsapkal@yahoo.com

DOI: $10.14260 /$ jemds $/ 2018 / 401$
Woman can become biologically fecund with menarche. Her capacity to bear the child comes to an end with the onset of menopause 44 - 49 years. Biological limits imposed on childbearing by age can be easily recognised as women conceive and give birth to the children within certain age limit. Thus, average reproductive span of any woman is of 30 - 35 years. Apart from this age of marriage and family size, both of them reflect the level and trend of urbanisation of the country. The demographic and cultural factors decide the family size of the community. Number of married years in the life of women can broadly be decided by knowing the age of marriage of a lady. Marriageable age is the age at which a person is allowed by law to marry either as a right or subject to parental or other forms of consent. Age and other prerequisites to marriage vary between jurisdictions, but generally is set at eighteen. Historically, the age for consent for sexual union has been determined by tribal custom. It was also a matter for families to decide 30 years ago. In those days, this used to coincide with signs of puberty: menstruation for women and pubic hair for men.

Age of marriage and size of the family are interconnected with each other. The marriage age should not be confused with the age of majority or the age of consent. It is important 
to identify the practical age wise group, who should be targeted for one or two child family norm. ${ }^{3}$ For certain age group, desired family size may also be very high. This group can be targeted for contraception practice. With this background, special health education programme can be organised for that specific age group. Thus, it will be easy to make the vast field of health workers narrow for feasibility of family planning services.

With this background, study was conducted with the hypothesis that there is marked increase in family size with early age of marriage. The study aims to explore the practiced age of marriage with its effect on family size. Thus, group of population can be analysed who are at risk to bear maximum children.

\section{MATERIALS AND METHODS}

A cross-sectional hospital-based study was conducted from June 2015 to September 2015, at tertiary health care centre located at Bhopal. Sample size of 1667 was selected as per convenience. Eligible patients for study included above 15 years, non-pregnant women and who gave consent to be part of the study.

Exclusion criteria were pregnant cases and women with mental disorders raising doubts of willingness to participate in the study.

Ethical clearance was sought from hospital ethics committee. Besides this, confidentiality was maintained. 1667 women were enrolled and interviewed in the study period of four months. Interviews were conducted in local language. All women were interrogated for their present age, age of marriage and number of child birth they had during their lifespan. Dead issues were excluded from family size.

\section{Statistical Analysis}

The data was collected and entered into personal computer. Categorical variables were summarised using frequency and percentages. The continuous variables were summarised using mean and standard deviation.

Statistical tests used were as follows- Chi-square test was used for arithmetic mean, standard deviation and for categorised parameters for comparative analysis. Level of significance was 0.05 .

Age of marriage data was divided into three slabs. Teenage marriage group was $<20$ yrs. A. Normal age marriage slab was 21 - 30 yrs.; B. Elderly group > 30 yrs. as age of marriage slab. C. Present family size in all three groups was noted. Dead issues were excluded from their present family size. The observations were compared and statistically analysed to know the relation between the age of marriage and family size (Table 2).

The objective of study was to know the effect of changing trends in family size in previous generations. Reproductive lifespan of each age group was calculated, and it was plotted retrospectively from study year as 2015. It was considered under the heading of generation gap. This data was correlated with their family size, Fig. 1.

\section{RESULTS}

In the sample of women interviewed, their current age was ranging from 18 - 70 years. Maximum of $61 \%$ were the age of
31 - 50 years. $32 \%$ were 18 - 30 years. Only $7 \%$ of population was 51 years and above till 70 yrs. Table 1 Mode age of women interviewed in the study was 35 years with standard deviation of $+/-9.56$. Mean age of population studied was 33 years and median value 30 years with standard deviation of + - 10.41. Maximum $48 \%$ had their average family size of three children with varying age of marriage.

Distribution of women in three slabs- Age of marriage was maximum at $83 \%$ teenage marriages (A), 16\% were married at the age of 20 - 30 years (B), only $0.6 \%$ was elderly group that was married after 30 years of age (C).

As regard to family size in three slabs was average 33\% had three children family in teenage marriage slab (A), 35\% had two children family and $31 \%$ one child family in normal age marriage group (B). However, in elderly marriage slab (C) $33 \%$ each had either no issue or single issue, Table 2.

When teenage marriage slab (A) was further analysed, maximum $25 \%$ each had three and four issues with marriage in childhood $5-14$ yrs. Chi-square value $=0.110, \mathrm{P}$ value $=$ 0.001 (highly significant). In marriage slab of $15-17$ years $32 \%$, slab of 18 - 20 years $35 \%$, both had maximum three children family size ( $\mathrm{p}=<.001$ highly significant) Table 2 .

On analysis of second slab of age of marriage as $21-25$ years (B) and estimated range of fertility period of $20-25$ yrs. maximum (35\%) had only two issues not three. Irrespective of generation gap, maximum two children family is the highly significant result (Chi-square $=159$, Degree of freedom $=42, \mathrm{P}$ value $=0.001$ ). In the same slab B $26-30$ years, $31 \%$ had one child in the family. However, with marriage age slab (C) > 31 - 35 years maximum $29 \%$ had 1 issue or no issue. It may be because mode age of women in the study is 35 years, Table 2 .

Before 1989 average family size was 3 - 5 children in equal proportion; 1990 - 1999 three children family size was the rule. After 2000 - 2004 two and three children in family were in equal percentage, but recently since last decade one and two children families are in equal proportion, Figure 1.

\begin{tabular}{|c|c|c|c|}
\hline Age Group & No. of Women Interviewed & \% & \\
\hline 18 to 20 & 21 & $01 \%$ & \\
\hline 21 to 25 & 211 & $13 \%$ & \\
\hline 26 to 30 & 307 & $18 \%$ & $32 \%$ \\
\hline 31 to 35 & 379 & $23 \%$ & \\
\hline 36 to 40 & 339 & $20 \%$ & \\
\hline 41 to 50 & 296 & $18 \%$ & $61 \%$ \\
\hline 51 to 60 & 87 & $05 \%$ & \\
\hline 61 to 70 & 25 & $01 \%$ & \\
\hline Above 70 & 2 & $0.0 \%$ & $7 \%$ \\
\hline Grand Total & $\mathbf{1 6 6 7}$ & $\mathbf{1 0 0 \%}$ & $\mathbf{1 0 0} \%$ \\
\hline \multicolumn{4}{|c|}{ Table 1. Distribution of Current Age of the Women } \\
Interviewed \\
\hline
\end{tabular}




\begin{tabular}{|c|c|c|c|c|c|c|c|c|c|c|c|}
\hline & Slab of Age of Marriage & $\mathbf{0}$ & 1 & 2 & 3 & 4 & 5 & $>6$ & $\begin{array}{l}\text { Grand } \\
\text { Total } \\
\end{array}$ & \begin{tabular}{|c|} 
Chi-Sq. and \\
Degree of Freedom \\
\end{tabular} & $\mathbf{P}$ \\
\hline \multirow{4}{*}{ A } & $\begin{array}{c}\text { Childhood Marriage } \\
5 \text { to } 14 \text { yrs. }\end{array}$ & $2 \%$ & $2 \%$ & $13 \%$ & $25 \%$ & $25 \%$ & $16 \%$ & $15 \%$ & $22 \%$ & 290,48 & 0.001 H Sig \\
\hline & $\begin{array}{l}\text { Teenage Slab } \\
15 \text { to } 17 \text { yrs. }\end{array}$ & $2 \%$ & $4 \%$ & $21 \%$ & $32 \%$ & $23 \%$ & $14 \%$ & $9 \%$ & $33 \%$ & 326,64 & $\begin{array}{l}0.001 \\
\text { H. Sig }\end{array}$ \\
\hline & $\begin{array}{c}\text { Age of Marriage } \\
18 \text { to } 20\end{array}$ & $5 \%$ & $25 \%$ & $24 \%$ & $35 \%$ & $16 \%$ & $12 \%$ & $2 \%$ & $45 \%$ & 0.110 & $\begin{array}{l}0.001 \\
\text { H Sig }\end{array}$ \\
\hline & All- $\mathrm{A}=83 \%$ & & & & & & & & 1390 & & \\
\hline \multirow{3}{*}{ B } & $\begin{array}{c}\text { Slab of Age of Marriage } \\
21-25 \mathrm{yrs} .\end{array}$ & $17 \%$ & $14 \%$ & $35 \%$ & $16 \%$ & $12 \%$ & $3 \%$ & $3 \%$ & $87 \%$ & 159,42 & $\begin{array}{l}0.001 \\
\text { H. Sig }\end{array}$ \\
\hline & $\begin{array}{c}\text { Age of Marriage } \\
26-30 \text { yrs. }\end{array}$ & $29 \%$ & $31 \%$ & $14 \%$ & $14 \%$ & $11 \%$ & & & $13 \%$ & $39.6,20$ & $\begin{array}{l}0.006 \\
\text { Sig }\end{array}$ \\
\hline & All- $\mathrm{B}=16 \%$ & & & & & & & & 268 & & \\
\hline \multirow[t]{3}{*}{ C } & $\begin{array}{l}\text { Elderly Group/ Age of } \\
\text { Marriage } 31 \text { to } 35 \text { yrs. }\end{array}$ & $33 \%$ & $33 \%$ & $11 \%$ & $22 \%$ & --- & & & 9 & 18,15 & $\begin{array}{c}0.264 \text { not } \\
\text { Significant }\end{array}$ \\
\hline & All- $\mathrm{C}=0.6 \%$ & & & & & & & & 9 & 18,15 & \\
\hline & Average $\%$ of Issues & $13 \%$ & $17 \%$ & $17 \%$ & $22 \%$ & $16 \%$ & $9 \%$ & $6 \%$ & $\begin{array}{l}1667 \\
\text { Total }\end{array}$ & & \\
\hline
\end{tabular}

Table 2. Distribution of Family Size in Different Age of Marriage Slab

\begin{tabular}{|c|c|c|c|c|c|c|c|c|}
\hline $\begin{array}{c}\text { Current } \\
\text { Age of } \\
\text { Women }\end{array}$ & \multicolumn{2}{|c|}{$\begin{array}{c}\text { Slab of Age } \\
\text { of Marriage }\end{array}$} & $\begin{array}{c}\text { Highest Percentage } \\
\text { of Women in } \\
\text { the Slab }\end{array}$ & $\begin{array}{c}\text { Number } \\
\text { of } \\
\text { Issues }\end{array}$ & $\begin{array}{c}\text { Slab of Age of } \\
\text { Marriage }\end{array}$ & $\begin{array}{c}\text { Second Highest } \\
\text { Percentage of Women } \\
\text { in the Slab }\end{array}$ & $\begin{array}{c}\text { Number } \\
\text { of } \\
\text { Issues }\end{array}$ \\
\hline $\begin{array}{c}41->50 \\
\text { yrs. }\end{array}$ & $5-14$ & $\begin{array}{c}\text { Childhood } \\
\text { Marriage }\end{array}$ & $(16 \%)$ & 4 & $18-20$ & Teenage & $(11 \%)$ & 3 \\
\hline $36-40$ yrs. & $15-17$ & Teenage & $(17 \%)$ & 3 & $15-17$ & $\begin{array}{c}\text { Child hood } \\
\text { marriage }\end{array}$ & $(15 \%)$ & 4 \\
\hline $36-40$ yrs. & $18-20$ & Teenage & $(18 \%)$ & 3 & $18-20$ & $\begin{array}{c}\text { Child hood } \\
\text { marriage }\end{array}$ & $(15 \%)$ & $(22 \%)$ \\
\hline $31-35$ yrs. & $18-20$ & Teenage & $(38 \%)$ & 3 & $15-17$ & Teenage & $(20 \%)$ & 2 \\
\hline $26-30$ yrs. & $18-20$ & Teenage & $(26 \%)$ & 3 & $18-20$ & Teenage & $(16 \%)$ & 2 \\
\hline $21-25$ yrs. & $18-20$ & Teenage & $(22 \%)$ & 1 & $18-20$ & Teenage & $(20)$ \\
\hline
\end{tabular}

Table 3. Teenage Slab of Age of Marriage - 15 - 20 yrs. (A) Distribution of First and Second Highest Percentage of Women with different Number of Issues

*Highest percentage of women with corresponding highest parity in slab (A) 15 - 20 yrs.

The second highest percentage of women and corresponding highest parity three in 15 - 17 years as age of marriage.

\begin{tabular}{|c|c|c|c|c|c|}
\hline $\begin{array}{c}\text { Slab of Age of } \\
\text { Marriage }\end{array}$ & $\begin{array}{c}\text { Slab of Age of } \\
\text { Marriage }\end{array}$ & $\begin{array}{c}\text { Current Age in } \\
\text { Yrs. }\end{array}$ & $\begin{array}{c}\text { Fertility } \\
\text { Period }\end{array}$ & $\begin{array}{c}\text { Population } \\
\text { Percentage }\end{array}$ & Children \\
\hline Teenage (A) & $5-14$ yrs. & $41-50$ & 35 yrs. & $29 \%$ & 4 \\
\hline Teenage (A) & $15-17$ yrs. & $31-35$ & $16-18$ yrs. & $26 \%$ & 2 \\
\hline Teenage (A) & $18-20$ yrs. & $31-35$ & $13-15$ yrs. & $27 \%$ & 3 \\
\hline Normal Age (B) & $21-25$ yrs. & $26-30$ & $5-10$ yrs. & $24 \%$ & 2 \\
\hline & $21-25$ yrs. & $41-50$ & $20-25$ yrs. & $22 \%$ & 2 \\
\hline Normal Age (B) & $26-30$ yrs. & $36-40$ & $10-15$ yrs. & $29 \%$ & 1 \\
\hline Elderly Age (C) & $31-35$ yrs. & & $1-5$ yrs. & $29 \%$ & 1 \\
\hline
\end{tabular}

Table 4. Distribution of Number of Issues, its Relation with Fertility Period in Three Slabs of Age of Marriage

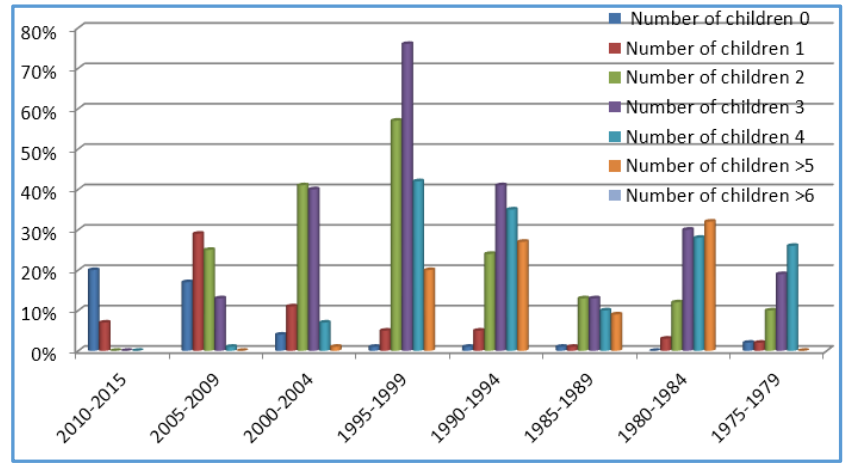

Figure 1. Family Size Trends observed retrospectively from year 2015 to Decades back to 1980

\section{DISCUSSION}

Overall, maximum $38 \%$ of study population had three issues. Least issue as one was observed with youngest recently married women. Their current age at the time of interview was 21 - 25 years. Their age of marriage slab was $18-20$ years. This slab is highest group with least number of issues as zero or one. Thus, fertility among women marrying late is lower than among those marrying at a younger age, Table 3.

In the first teenage group $<20$ yrs. of marriage slab (A) maximum $29 \%$ had four issues with fertility period of $35 \mathrm{yrs}$, $27 \%$ had three issues in family with relatively less fertility period of 13 - 15 yrs.

Family size is also variable according to their current age at the time of interview. For example, in young patient as they 
might have not completed their childbearing age. Current age range of 31 - 35 yrs., age of marriage slab 18 - 20 years, fertility period of 13 - 15 yrs., $27 \%$ had three issues.

In old women with current age of 41 - 50 and above with childhood marriage and fertility period of 35 yrs. maximum (29\%) four and above issues were seen. In the same age group of 41 - 50 yrs. with age of marriage slab as $21-25$ years and less fertility period of 20 - 25 yrs., maximum $22 \%$ had two issues. Thus, if marriage slab is with more age number of issues are less. Hence, advisable effective age of marriage can be as 21 - 25 years, Table 4 .

In the group (C) with age of marriage above 30 years family with no issue or family with three issues, both were $33 \%$ each. It may be because mode age of study population was 35 yrs.

In the present study in populations with higher age at marriage, fertility is generally observed to be low. It is recently married population in the study. Sample interviewed of married women at age of 31 - 35 yrs. (C) also was too small to comment on. ${ }^{3}$ Bongaarts in 1982 also commented that advancing marriage age can lower fertility. Smith PC et al ${ }^{4}$ in 1983 observed that effects of marriage pattern on fertility depend on reduced exposure to intercourse and also on shifting of childbearing age to older ages.

Coale et al $^{5}$ (1992) observed the relationship between late marriage and low fertility is the result of higher control levels of marital fertility among the populations that marry late. By advancing age of marriage from 26 - 30 or 31 - 35 years, the family size reduces one child or no child irrespective of varying contraceptive trends in decades.

Ahmed et al 1981 found clear negative association between ages at marriage and family size. When marriage age increases under these conditions, fertility can be declined because of the reduced number of years at risk of childbearing. Kaur et $\mathrm{al}^{7}$ (2000) stated that higher age at marriage shortens the reproductive span, which in turn reduces the fertility rate.

Fig. 1 reveals before 1989, average family size range was 3 to 5 children family size were in equal proportion. Then, there was periodic but dramatic change from 5 children to 3 children family. Three child norm was stationary for one decade from 1990 - 1999. After 2000 - 2004 two and three children in family are in equal percentage. Recently, last five years 2005 - 2010 one and two children families were in equal proportion.

Thus, whatever may be the generation gap two child family is the result with the age of marriage range of $21-25$ years. (Chi-square $=159$, Degree of Freedom $=42, \mathrm{P}$ value $=$ 0.001 (highly significant). In the present study, teenage marriages are still widespread. Fertility period is the major determining factor for family size. Age of marriage is the bottom line for knowing fertility span.

\section{CONCLUSION}

Average age of cohabitation in the present study is 18 - 28 years. In populations with higher age at marriage, fertility is generally observed to be low. Results are matching with the study conducted by Smith PC et al. ${ }^{4}$ Shifting of childbearing to older ages will have changes in the mean length of a generation.

The earliest age to prevent the third child is women with age 26 to 30 years and age of marriage as $18-20$ years. In short, slab of age of marriage which needs attention for prevention of the third issue is 18 - 20 years age of marriage. This population with three issues is $80 \%$ in the present study.

To conclude target population for permanent contraception to prevent third child birth is any lady of current age of 31 - 35 years.

\section{Impact of Study}

This study provides evidence based data of women who opted for marriage at different age with different family size for evaluation. Fertility period is the major determining factor. Hence, rising age of marriage will help in lowering the birth rate.

\section{REFERENCES}

[1] Nag A, Singhal P, Kamla-Raj. Impact of education and age at marriage on fertility among Uttar Pradesh migrants of Ludhiana, Punjab, India. Anthropologist 2013;15(2):225-30.

[2] Breierova L, Duflo E. The impact of education on fertility and child mortality: Do fathers really matter less than mothers? OECD, no. 217, 2004.

[3] Bongaarts J, Frank O, Lesthaeghe R. The proximate determinants of fertility in Sub-Saharan Africa, Washington, D.C., The World Bank, 1990: p. 133-43. (A World Bank Symposium).

[4] Smith PC. The impact of age at marriage and proportions marrying on fertility. In: Rodolfo A, Bulatao, Lee RD, et al. eds. Determinants of fertility in developing countries. Vol 2. New York: Academic Press 1984: p. 473-531.

[5] Coale A. Age of entry into marriage and the date of initiation of voluntary birth control. Demography 1992;29(3):333-41.

[6] Ahmed KS, Chaudhary RH. Nuptiality population of Bangladesh country monograph Series no. 8, Economic and Social Commission for Asia and The Pacific, Bangkok, Thailand, 1981.

[7] Kaur Hr. Impact of income and education on fertility. Journal of Family Welfare 2000;46(1):70-6. 